\title{
Correction:
}

\section{Effects Of Exchange Rates On International Transfer Pricing Decisions}

Canri Chan, (E-mail: canri.chan@miis.edu), Monterey Institute of International Studies Steven P. Landry, (E-mail: steve.landry@ miis.edu), Monterey Institute of International Studies Terrance Jalbert, (E-mail: jalbert@ hawaii.edu), University of Hawaii at Hilo

The following Table was submitted by the authors as an update, however, the International Business \& Economics Research Journal, Volume 3, Number 3, page 39 had already gone to press. We apologize for any inconvenience.

Table 2: Summary Of The Current Rate Method And The Temporal Method Of US FAS No. 52 (Sources: Choi et al 2002; Fischer et al 2002)

\begin{tabular}{|c|c|}
\hline Current Rate Method & Temporal Method \\
\hline $\begin{array}{l}\text { I/S items - prevailing current rate or weighted-average } \\
\text { exchange rate }\end{array}$ & I/S items - weighted-average exchange rate \\
\hline All assets \& liabilities - current rate & $\begin{array}{l}\text { Monetary items - current rate } \\
\text { Nonmonetary items: } \\
\text { Items carried at historical cost - historical rate } \\
\text { Items carried at fair (current) value - current rate }\end{array}$ \\
\hline $\begin{array}{ll}\text { iity } & \text { - historical rate } \\
& - \text { current income added to retained earnings using } \\
& \text { current rate or weighted-average }\end{array}$ & $\begin{array}{ll}\text { Equity } & - \text { historical rate } \\
& - \text { current income added to retained earnings using } \\
& \text { current rate or weighted-average }\end{array}$ \\
\hline \multicolumn{2}{|c|}{$\begin{array}{l}\text { - if local currency is functional currency, use current rate method (translation gains/losses are included in the Shareholders' Equity section on } \\
\text { the } \mathrm{B} / \mathrm{S} \text { ) } \\
\text { - if the dollar is the functional currency, translate foreign currency to US\$ using temporal method (translation gains/losses are included in the } \\
\text { Income Statement) } \\
\text { - if the dollar is not the functional currency, translate foreign currency to functional currency using temporal method first (translation } \\
\text { gains/losses are included in the Income Statement), and then translate functional currency to dollar using current rate method (translation } \\
\text { gains/losses are included in the Shareholders' Equity section on the B/S) } \\
\text { - } \mathrm{I} / \mathrm{S}=\text { Income Statement } \\
\text { B/S = Balance Sheet }\end{array}$} \\
\hline
\end{tabular}


Notes 